\title{
ESITTÄVÄN JA SÄVELTÄVÄN TOIMINNAN SUHDE JA JAZZ-MUSIIKKI
}

Esitys • sävellys • sovitus - tulkinta - improvisaatio - "kaava" • teoria • analyysi • estetiikka

Esittävä ja säveltävä toiminta ihanteineen ja ominaisuuksineen erottuvat toisistaan kahdeksi dialektisessa vuorovaikutussuhteessa olevaksi musiikillista käytäntöä leimaavaksi ilmiöksi. Esittävän toiminnan kulttuurikontekstia voidaan kutsua esim. virtuoosikulttuuriksi ja säveltävän toiminnan piiriä teostietoiseksi musiikkikulttuuriksi. Tämä jaottelu soveltuu sellaisenaan kuitenkin vain länsimaisen taidemusiikin tarkasteluun; yleisemmin voidaan puhua esittäjä- ja säveltäjäkeskeisistä kulttuurityypeistä.

Carl Dahlhaus on todennut virtuoosikulttuurista kirjassaan Die Musik des 19. Jahrhunderts seuraavasti (1980:113; käännös kirjoittajan):

Konserttisaleissa ja oopperassa esiintyy virtuoosi 1700 -luvulta varhaiselle 1800 luvulle asti erityisen musiikkikulttuurin edustajana. Musiikilliset tekstit ovat pelkkiä esityksen "kaavoja" ("Vorlagen" für Aufführung), joiden esteettinen polttopiste ei ole teos vaan soittaja tai laulaja itse. Teksti oli tällöin esityksen funktio, eikä päin vastoin, kuten tulkintapainotteisessa esityksessä.

1800-luvun puolivälissä voidaan eurooppalaisessa taidemusiikkielämässä nähdä selvä rajakohta, joka mielenkiintoisella tavalla osuu yhteen yleisessä ja sosiaalihistoriassa merkittävien vuoden 1848 tapahtumien kanssa. Fried- 
rich Wieck, jolla oli sisäpiirin näkökulma ajan musiikkiin, tarkensi virtuoosikulttuurin kriisin vuosiin 1848 - 1849 (Wieck 1853:116). Dahlhausin mukaan puhtaasti musiikilliselta kannalta ratkaiseva tekijä oli ns. Paganinielämys, joka osoitti, että virtuoosisuus voidaan ottaa osaksi romanttisen musiikin modernistisia pyrkimyksiä. Franz Lisztille, joka oli kasvanut paljolti artistisen virtuoosisuuden piirissä, tämä merkitsi murrosta musiikillisessa ajattelussa (Dahlhaus 1980:111). Sadan vuoden ajan - 1850 - 1950 teostietoisuuden ja säveltäjäkeskeisyyden ihanne vakiintui siinä määrin, että erityisesti vanhempaan musiikkin nähden on vaikea rekonstruoida vastakkaista näkökulmaa. Modernissa aleatoriikassa säveltäjän ja esittäjän roolien vertailusta on keskusteltu sen sijaan niin paljon, että on kenties mahdollista laajentaa kysymyksenasettelua vanhempaankin musiikkiinkin. Toisaalta muun kuin länsimaisen taidemusiikin tutkimuksessa kysymys ei ole vakiintuneiden paradigmojen kumoamisesta vaan yksinkertaisesti tutkimuksen syventämisestä. Samalla voidaan yrittää etsiä yhteisiä tutkimusstrategioita taide- ja muun musiikin välille.

Mielenkiintoista kyllä, teostietoisuus liittyy kiinteästi yhteen niin sanotun historiallisen tietoisuuden kanssa - paitsi sikäli, että molemmat tunnistetaan samoissa kulttuuripiireissä, myös sikäli, että toinen johtaa olemuksellisesti toiseen. Historiallinen tietoisuus tarkoittaa, että esitystä ei koeta pelkästään tapahtumana (vrt. G. W. Hegelin "Ereignischarakter der Musik"). Huomion keskittyessä esitettäviin teoksiin, jotka ikään kuin kantavat mukanaan omaa historiallista luomistilannettaan, kuuntelija erkanee tapahtumahetkestä taidehistoriallisiin ulottuvuuksiin. Musiikissa, jossa teos tms. joko syntyy esityshetkellä improvisation muodossa tai on merkitykseltään sekundaarinen - kuten virtuoosikulttuurin piirissä - esitystapahtuman asemaa esteettisen kokemisen keskuksena ei vähennä esitystapahtuman ulkopuolinen - esim. historiallinen - tietoisuus. Vaikka nykyisin ei enää voidakaan sanoa, että kaikki taide on luonteeltaan edellä kuvatussa mielessä "historiallista", teoskeskeinen taide on sitä aina. Mitä suurempi merkitys esitystapahtumalla on, sitä vähemmän "historiallista" musiikki luonteeltaan on.

\section{"Kaava", sävellys ja tulkinta}

"Kaavojen" laatimisella tarkoitan kaikkea esitystä edeltävää suunnittelevaa toimintaa, jonka piiriin kuuluu mm. säveltäminen. "Kaava" ei kuitenkaan ole sama kuin sävellys: "kaava" voi olla esim. improvisaation runko, jokin sävelmä tms. Teos-"kaava" vastaa sävellystä taidemusiikillisessa mielessä vain, mikäli sävellyksen käsitettä ei sidota nuotinnokseen, sillä "kaava" on 
suunnitelma täydelisessä intentionaalisessa mielessä. "Kaava" ei silti välttämättä sisällä kaikkia esityksen aspekteja - "kaava" voi sisältää myös vaatimuksen täydentää sitä esityksen yhteydessä. Toisaalta "kaavat" jakautuvat yleisiin ja spesifisiin sen mukaan, koskevatko ne tiettyjä esityksiä vaiko kaikkea tietyn musiikkikulttuurin piirissä tapahtuvaa toimintaa. Edelleen myös esittäjä, ennen kaikkea ns. tulkitsija, voi toimia "kaavan" laatijana tehdessään edeltä käsin suunnitelmia varsinaisen esityksen varalle. Tämä on yleistä niin improvisaation kuin tulkinnankin piirissä; tulkinnaksi voidaankin oikeastaan kutsua vain sellaista esittävää toimintaa, joka ensinnäkin perustuu spesifiseen "kaavaan" pyrkien eksplisiittisesti noudattamaan sitä; toisaalta se edellyttää esitystä ennakoivaa, sitä suunnittelevaa toimintaa. Prima vista -tulkinta on lähinnä paradoksi, joka on mahdollinen ainoastaan sellaisen musiikkikulttuurin piirissä, jossa yleiset "kaavat" ohjaavat sekä säveltävää että esittävää toimintaa siinä määrin, että esittäjä voi luottaa yleiseen "kaavojen" tuntemukseensa. Täydellistä tämä harvoin on: jopa 1700-luvulla - musiikissa, joka perustui Ratnerin mukaan tooppeihin, tietynlaisiin verrattain spesifisiin yleisiin "kaavoihin" (Ratner 1980) - Leopold Mozart kirjoitti, että esittäjän on luotava huolellinen yleissilmäys esittämäänsä kappaleeseen ennen kuin hän alkaa soittaa tai laulaa sitä, jotta hän saisi käsityksen sen yleisilmeestä - siis toopista ja yleisistä "kaavoista".

Säveltävän toiminnan kuvaaminen "kaavojen" eli esitystä koskevien suunnitelmien laatimisena ei tosin ole yleistä, muttei aivan radikaalisti uuttakaan. Ensinnäkin on improvisaation tutkimuksessa jo kauan puhuttu kaavoista ja malleista (kuten raga, maqam yms.; vrt. esim. Nettl 1974) ja huomattu, etteivät improvisaatio- ja sävellysperinteiden rajat ole äkkijyrkkiä. Toisaalta musiikin estetiikan piirissä on viime vuosikymmeninä käyty varsin vilkasta keskustelua teoksen olemuksesta, mikä on tuonut esille monia "kaava"-käsitteen sovellettavuutta tukevia näkökohtia, joihin on tässä aiheellista paneutua.

Zofia Lissa on lähestynyt kriittisesti Roman Ingardenin teoriaa, jonka mukaan musiikin teokset ovat enemmän tai vähemmän epätarkasti määriteltyjä skeemoja, jotka saavat konkreettisen muotonsa vasta esityksessä. Ensi silmäyksellä Ingardenin tunnetut teesit teoksen olemuksesta vaikuttavat ehkä "kaavan"-konseptin kanssa identtisiltä, mutta Lissan kritisoima nuotinnoksen korostus teoksen olemuksellisena perustana paljastaa tärkeän eron, onhan "kaava" nuotinnoksesta riippumaton. Lissan tarkoitus on paljastaa teoksen olemus uudesta, Ingardenia modernimmasta näkökulmasta. Kuitenkin Lissankin mielestä vasta nuotinnettu teos on valmis; nuotinnoksen asema teosta rajaavien kriteerien joukossa on siis edelleenkin keskeineı (vrt. Lissa 1975:8-). Sen sijaan Rafal Nowackin kritiikki Ingardenia kohtaan on pidemmälle vietyä: Nowackin mukaan sävellys koostuu jou- 
kosta "tekstejä" - ensinnäkin säveltäjän laatimasta graafisesta tekstistä ja toisaalta reproduktioista. "Tekstit" eivät kuitenkaan ole sikäli keskenään täysin saman arvoisia, että reproduktio-teksti on riippuvainen graafisesta tekstistä (Nowacki 1982:103-112). Voidaankin kysyä, mitä hyötyä näin yleisestä teksti-käsitteestä on? Joka tapauksessa Ingardenin luoma kahtiajaottelu ("skeema - konkreettinen muoto") on väistynyt esittäjän ja säveltäjän toiminnan rinnastavan konseption tieltä.

Thomas C. Markin näkökulma, jonka mukaan teoksen esitys on sen samanaikaista siteeraamista ja "väittämistä" (Mark 1981:313), tuo mielenkiintoisella tavalla esiin esittävän toiminnan kaksitasoisuuden: toisaalta siteerataan jotain jo olemassaolevaa, toisaalta toimitaan ehdottoman itsenäisesti - aidossa mielessä luovasti, omaehtoisesti "väittäen". "Väite" perustuu siihen, että esittäjä pyrkii saamaan aikaan jonkin tietyn vaikutuksen - ilman tätä intentioa esitys on pelkkä sitaatti. Stravinskyn objektiivisuus-vaatimus, että esittäjän tulee pelkästään toteuttaa nuotinnos - ei tulkita sitä - , näyttäisi Markin kategorioihin suhteutettuna merkitsevän siteerauksen vaatimusta (Stravinsky 1957:236). Sellisti Siegfried Palmin mukaan tämä vaatimus on kuitenkin "yksi Stravinskyn suurista erehdyksistä, jota hän itse kaikkein vähiten noudatti" (k. Lück 1971:133); toisaalta Stravinsky itsekin veti vaatimuksensa osittain takaisin, mikä kertoo sen olleen lähinnä poleemiseksi tarkoitettu.

Ferruccio Busonin mukaan niin tulkinta kuin notaatiokin ovat vain transkriptioita alkuperäisestä ideasta, joka menettää osan ominaisuuksistaan heti säveltäjän nuotintaessa sitä ja jota ei mikään muu musiikin olomuoto ("transkriptio") voi sivuuttaa (Busoni 1956:125). Busonin alkuperäinen idea vastaa aivan ilmeisesti tässä tarkoittamaani "kaavaa" länsimaisessa taidemusiikissa. David Pickett kertoi luennollaan (Musiikin murros -seminaari 19.11.1987) Mahlerin ymmärtäneen johtamiensa teosten "Urtextin" samaan tapaan: "Urtext" ei ollut säveltäjältä säilynyt nuotinnos, vaan oletus säveltäjän varsinaisesta suunnitelmasta, jota tämä ei aina ollut ehtinyt tai kyennyt yksityiskohdittain nuotintamaan. Näin ajatellen myös Hugo Riemann - ja monet muut 1800-luvun lopussa - korjailivat säveltäjän nuotinnoksia nimenomaan siinä tarkoituksessa, että varsinainen tarkoitus tulisi näin paremmin esiin. Tällaisella menettelyllä on sikäli historiallinen oikeutuksensa, että vasta vähitellen 1800 -luvulla yleistyi Beethovenin postuloima pyrkimys todella nuotintaa kaikki mahdollinen mahdollisimman tarkasti; missä määrin tämä on aina utopia, on tietysti kysymys sinänsä. 
Jazz on ns. kevyen musiikin sektoreista se, jonka kosketuskohdat 20. vuosisadan taidemusiikkikulttuuriin ovat olleet kiistatta kaikkein monipuolisimmat. Vaikutteita on kulkenut "rajan" yli molempiin suuntiin ja eräät esittävät ja säveltävät taiteilijat ovat tulleet tunnetuiksi molempien alojen edustajina. Niin taide- kuin jazzmusiikin harrastajat katsovat kuuluvansa erityiseen spesialistiryhmään. Jopa Th. W. Adorno puhui jazz-eksperteistä, vaikka luonnehtikin heitä monin verroin kriittisemmin kuin varsinaisia "eksperttejä" (musiikillisen käyttäytymisen 1. ja 6. tyyppi; Adorno 1975:17-28). Varsinainen ekspertti on Adornon mukaan tiedostava, reflektiivinen kuuntelija, joka tuntee sävellystavat ja -periaatteet ja osaa myös arvioida niiden käyttöä. Jazz-ekspertti arvostaa spontaanisuutta ja osallistumista ja haluaisi usein "vaihtaa esteettisen asenteen teknis-urheilulliseen" (mts. 27). Jazz-kulttuuria voidaan Adornonkin typologian perusteella luonnehtia esittäjä- ja esitystapahtumakeskeisemmäksi kuin varsinaisten eksperttien edustamaa taidemusiikkikulttuuria. Tarkasteltaessa nimenomaan musiikin tyylipiirteitä on syytä mainita ainakin kaksi tyylillistä risteyskohtaa: Ravel-Gerschwin-Milhaud'n (muiden muassa) musiikki ja progressiivinen orkesterijazz 1970-luvulta alkaen (esim. Jukka Linkolan Crossings, 1984).

Improvisaatio liitetään euro-amerikkalaisten musiikkilajien piirissä useimmiten juuri jazziin. Jotkut, kuten Mark C. Gridley, esittävät jazzin määrittelemistä musiikiksi, joka improvisoidaan ja jossa on "swing feeling" (Gridley 1978: 11-22). Joachim Berendtin määritelmä sisältää kolme kohtaa (Berendt 1976: 174):

1. A special relationship to time, defined as "swing".

2. A spontaneity and vitality of musical production in which improvisation plays a role.

3. A sonority and manner of phrasing which mirror the individuality of the performing jazz musician.

Tämä määritelmä voidaan pelkistää kahteen kriteeriin - "svengaavaan" rytmiin (1. kohta) ja esittävän muusikon toiminnan tärkeyteen ja sen intensiivisyyteen (2. ja 3. kohta). Esittäjän toiminnan keskeisyys korostuu siinäkin, että "jazz-improvisaatiota ei voi reprodusoida kukaan muu kuin alkuperäinen improvisoija, improvisaation tuottaja" (mts. 128).

Berendt kutsuu improvisoijaa sekä säveltäjäksi että tulkitsijaksi (mts. 128-130). Toisaalta hän kirjoittaa, että "jokainen jazz-improvisaatio perustuu teemaan" ja "perinteisen jazzin varsinainen improvisaatio-osuus on tee- 
maa seuraava chorus" (mts. 126-127). Tähän kiinnittää huomiota myös Gridley kirjoittaessaan, että improvisaatio alkaa yleensä siitä, mihin "sävelmä" loppuu, ja loppuu siihen, missä "sävelmä" jälleen alkaa (Gridley 1978: 14). Edellä esitellyn "kaava"-mallin mukaan säveltäjäksi voidaan kutsua vain henkilöä, joka etukäteen laatii suunnitelman esitystä varten. Niinpä improvisoija ei läheskään aina ole säveltäjä - ainoastaan valmistaessaan improvisaationsa etukäteen. Improvisaatiomuotoja voidaan puolestaan luokitella mm. sen mukaan, miten ne suhtautuvat "sävelmään". Kaksi jo André Hodeirin määrittelemää päätyyppiä ovat "parafraasi" ja "chorus-fraasi": parafraasi tarkoittaa "sävelmän" koristelua, täydentämistä - chorus-fraasi puolestaan sävelmän harmonisten kulkujen pohjalta improvisoituja täysin uusia melodioita (Hodeir 1954, Hommes et problemes du jazz ; ks. Berendt 1976: 126-127). 1930-luvulta alkaen saatettiin big band -musiikissa laatia "sävelmän" tueksi ns. "head arrangement", "pääsovitus" (mts.132). Niinpä "säveltäjäksi" voidaan jazz-musiikissa kutsua paitsi "sävelmän" tekijää, myös sovittajaa.

Joissain tapauksissa jazz-improvisoija joutuu tietysti laatimaan itselleen improvisaatio-"kaavan", joskus se on valmiiksi laadittu. Orkesterijazzissa solistit improvisoivat kukin vuorollaan siten, että ennalta sävelletty tekstuuri ei joudu improvisaation kanssa ristiriitaan; improvisaatio-"kaava" on siis implisiittisesti valmiiksi laadittu orkesterille sävelletyn tekstuurin ja ns. sovituksen muodossa. Toisaalta yhtäaikaa improvisoivat jazzmuusikot joutuvat yhdessä sopimaan "kaavasta". Yhtyeet saattavat opetella valmiita johdanto- ja päätösjaksoja, jolloin esityksen perustana olevan "kaavan" yksityiskohtaisuusaste vaihtelee esityksen kuluessa hyvinkin yksityiskohtaisesta melko vapaaseen. Esimerkiksi Miles Davis on kertonut suosineensa 1950-luvulta alkaen harmonisten kulkujen sijasta skaaloja "improvisaatiokaavoinaan" - tekniikka, jota kutsutaan myös "modaaliseksi improvisaatioksi". Niinpä Gil Evans kirjoitti Davisille pelkän skaalan "kaavaksi" sovittaessaan Gerschwinin Porgyn ja Bessin big bandille (ks. Berendt 1976: 96; 130-135).

Alfons M. Dauer on tutkinut jazz-kulttuuria afrikkalaisista puhallinorkesteritraditioista käsin ja todennut, että jazzin ja improvisaation liittäminen yhteen ei - vastoin vielä nykyisinkin melko yleistä käsitystä - pohjaudu afrikkalaiseen "vapaaseen improvisaatioon". Dauer puhuu improvisaatiosta seuraavanlaisissa tapauksissa:

1. variantit sävelmateriaalin puitteissa, perustuen "esiintyöntymisen ja vetäytymisen tekniikkaan" suhteessa muuhun soitinryhmään (Dauer 1985: $51)$;

2. melodiset (instrumentaali-)jaksot, jotka eivät toistu muiden jaksojen lailla samassa muodossa useita kertoja (mts. 88); 
3. melodiset variantit (erilaisin keinoin) tietyn perusmelodian pohjalta (mts. 100);

4. lyömäsoittajien solistiset "ad libitum" -jaksot tiettyjen rytmismelodisten "mallien" puitteissa (mts. 115) ja

5. asteittainen variointi tietyn "sävelsukulaisuus-asteikon" mukaan (mts. 132).

Näistä afrikkalaisen musiikin piirteistä, joissa musiikillinen prosessi on keskimääräistä enemmän yksittäisen esittäjän spontaanin kekseliäisyyden varassa - muttei tietenkään täysin "vapaata" - , kehittyivät Dauerin mukaan jazz-improvisaation "kaavat". Dauerin tapaus 2 vastaa edellä mainittujen jazz-tutkijoiden käsitystä, jonka mukaan improvisaatio alkaa siinä, missä "sävelmä" loppuu jne.: toistuvat melodiat ovat "sävelmiä", niistä selvästi poikkeavat, ainutkertaiset jaksot puolestaan improvisaatioita.

1960-luvun jälkeen jazz-kulttuurissa on esiintynyt monia mielenkiintoisia improvisaatiotapoihin liittyviä innovaatioita, kuten esimerkiksi Ornette Colemanin ajatus, jonka mukaan musiikin säännöt eivät saa olla ulkoapäin tuotuja (kuten harmonian kulun standardit) vaan soittimesta ja "sävelmästä" käsin löydettyjä; tällöin soittaminen on soittimen ja "sävelmän" ilmaisumahdollisuuksien jatkuvaa, improvisoivaa etsimistä (ks. Berendt 1976: 104). Musiikin tuottamistapaa, jossa soitin ja soittaminen toimivat keskeisenä inspiraation ja musiikillisten ideoiden "generoijana", voidaan kutsua "soittimelliseksi" ja "soittimelliseen ajatteluun" perustuvaksi (vrt. Mäkelä 1987: 189: "--"soittimellinen ajattelu" eli tapa tuottaa tai tulkita musiikkia siten, että musiikillisen prosessin lähtökohtana on käytetyn soittimen yms. rakenteeseen ja käyttötapaan liittyvät erityispiirteet eli "soittimelliset kriteerit" --"). "Soittimellisuus" on siten yksi tärkeimpiä kysymyksiä, kun tutkitaan musiikkia nimenomaan esittävänä säveltaiteena. Jazzissa sen merkitys lienee vielä taidemusiikkikulttuuria suurempi, kuuluuhan jazz jälkimmäistä selvästi esittäjäkeskeisempään musiikkikulttuurityyppiin.

André Hodeir - tunnettu ranskalainen jazz-teoreetikko - on kirjoittanut aiheesta seuraavasti (1954; ks. Berendt 1976:157-158):

Eurooppalaisessa traditiossa säveltäjät laativat säveljaksot sellaisenaan ja muovaavat ne sen jälkeen tietyille soittimille sopivaan muotoon. Jazz-improvisoija luo instrumenttinsa ehdoilla sitä soittaessaan. Soittimesta tulee ääritapauksissa ikään kuin osa häntä itseään ...

Hodeirin suuri virhe on eurooppalaisen tradition yksinkertaistaminen, sillä onhan toki selvää, että eurooppalaisen taidemusiikin tyylilliseen kirjoon mahtuu hyvin erilaisia suhtautumistapoja niin soittimellisuuteen kuin mui- 
hinkin kysymyksiin. Sama pätee tosin myös jazziin. Jazzin piirissä tunnetaan kuitenkin yksiselitteisesti soittimellisia piirteitä, kun taas taidemusiikissa tutkimusta vaikeuttaa - tehden siitä samalla mielenkiintoisempaa - se, että soittimellinen ajattelu on monin tavoin integroitunut ekspressiivis-konstruktiivisiin tekijöihin.

Alois Mauerhofer on puolestaan tutkinut flamenco-soittoa "spesifisen kitaratekniikan soivana ilmaisuna". Flamenco on improvisaatiopohjainen esityskäytäntö, jota ohjailevat muodon, rytmin, sävellajin ja ilmaisukarakteerin suhteen verrattain yksityiskohtaiset genre-"kaavat" kuten alegria, soleares, buleria jne. Näistä huolimatta esittäjän spontaanille ilmaisulle ja improvisaatiolle jää paljon tilaa; juuri muunosten teon taito on arvostusperuste esittäjien keskuudessa (Mauerhofer 1979:103). Jaottelussa yleisiin ja spesifisiin genre-"kaava" kuuluu edelliseen tyyppiin. Koska flamencosoittajat eivät yleensä osaa nuotteja, kappaleet opitaan soittajayhteisöä tarkkailemalla. Soittotekniikoilla on omat nimensä: samaan tapaan kuin japanilaiset koto-soittajat mieltävät flamenco-kitaristitkin esittämänsä musiikin paitsi soivien piirteiden, myös soittotekniikkojen kautta. Rasqueado tarkoittaa perättäisten akordien nopeasti etenevää ketjua ja siitä tunnetaan useita alalajeja, picado yhden kielen peräkkäistä näppäilyä suoristetulla oikean käden etusormella ja nimettömällä, golpe joko oikean käden etusormen tai pikkusormen tapaa koputtaa kaikukoppaa ja parado tapaa aikaansaada kuiva staccatoakordi vasemman käden avulla. Nämä ja monet muut soittotavat muovaavat flamenco-tyyliä (soittimellisten) "yleisten kaavojen" lailla: vakiintuneet soittotavat säilyvät traditiossa sukupolvelta toiselle ja vaikuttavat sekä suoraan (improvisaatiomahdollisuuksia rajaamalla) että epäsuoraan (esittäjien musiikillisen mielikuvituksen kautta) flamencosävelmien tyyliin. Vaikka Mauerhofer rinnastaakin flamencon jazziin, merkittävä ero on soittimellinen konservatiivisuus: jazzin piirissä soittimelliset innovaatiot ovat jokapäiväisiä - Colemanin mukaan osa musiikillista ilmaisua.

Niin oudolta kuin tulkinnan käsitteen liittäminen jazz-kulttuuriin saattaakin tuntua, sen mukaan ottaminen on välttämätöntä. Perinteinen jazzimprovisaatio on usein improvisaatiota jonkin "sävelmän" pohjalta. Toisaalta improvisaatioista on vähitellen vakiintunut eräänlaisia "sävellyksiä", joita on myös nuotinnettu - yleensä tosin transkriptioina ("as recorded by --"; esim. Oscar Peterson Jazz Piano Solos . New York: Ch. Hansen.). Jazz-"sävellykset" tunnistetaan yhtäältä - taidemusiikin sävellysten lailla - niiden nimen perusteella ja toisaalta niiden esitykset muistuttavat toisiaan ainakin suurin piirtein. Esimerkiksi Peterson on levyttänyt originaalisävel-lyksensä L'Impossible (Tomi Music Co.) ainakin kahdesti, 3.12.1965 Chicagossa Ray Brownin ja Luis Hayesin kanssa ja 9.11.1983 
Berkeleyssä Joe Passin, Martin Drewin ja Niels Henning Örsted-Pedersenin kanssa; edellisen version pituus äänilevyllä on 5"20 (Mercury 6641577), jälkimmäisen 6"00 (Pablo 2310-918). L'Impossible ei ole pelkkä sävelmä- vaan yksityiskohtainen improvisaatio- tai teos-"kaava", josta on olemassa kaksi tulkintaa (ks. Kaavio 1).

Tulkinnalla on aina kohde ja musiikillisena toimintana sille on ominaista pyrkimys noudattaa suunnitelmaa eli valmiiksi laadittua "kaavaa" ja etsiä sen merkitystä (joka tosin saattaa sisältää vaatimuksen improvisoida). Kun jazz-kulttuurissa puhutaan tulkinnasta, on selvää, että siihen liittyy aina improvisaatiota. Kysymys on siis kulloinkin ensisijaisesta toimintamuodosta eli suhteellisuudesta. Se, puhutaanko tällöin teos- vai improvi-

Kaavio 1: Oscar Peterson, L’Impossible 1965 ja 1983

\begin{tabular}{|c|c|c|c|c|c|c|}
\hline & A & $\begin{array}{l}A^{\prime} \\
\text { teema/piano }\end{array}$ & $\begin{array}{l}\text { BI } \\
\text { impr1/piano }\end{array}$ & $\begin{array}{l}\mathrm{Bl}^{\circ} \\
- \text { impr } 1 \% / \text { piano }\end{array}$ & $\frac{\mathrm{Bl} \text { " }}{\text { impr 1" /piano }}$ & $\frac{A^{\prime}(1 / 2)+\operatorname{coda}}{-t e e m a 1 / 2+\operatorname{coda}}$ \\
\hline & & $\begin{array}{l}\text { bassotrummut } \\
\text { (perussöestys) } \\
\therefore \ldots \ldots\end{array}$ & $\begin{array}{l}\text { kuvio } \\
\text { rummut kuten } \\
\text { edella }\end{array}$ & basso+rummut & $\left\{\begin{array}{l}\text { basso+rummut } \\
\text { kuten Bi sisá }\end{array}\right.$ & $\begin{array}{l}\text { bassotrummut } \\
\text { (perussäestys) } \\
\text { basso improvi- } \\
\text { soi lopukkeen } \\
.\end{array}$ \\
\hline
\end{tabular}

(kesto 5'20)

1983:

\begin{tabular}{|c|c|c|c|c|c|}
\hline $\mathrm{Ai}$ & $\mathrm{Ai}^{\prime}$ & $A i^{\prime \prime}$ & Al & $\mathrm{Al}^{\circ}$ & $\mathrm{Al}^{\prime \prime}$ \\
\hline teema/piano & - teeman runko/p & - teeman runko/p & -impr/piano & Himpr* * piano & Himpr **/piano \\
\hline impr/kitara & -impr '/kitara & -impr "/kitara & - impr '"'/kitara & - impr" "/kitara & - impr" "'/ kitara \\
\hline $\begin{array}{l}\text { basso+rummut' } \\
\text { (perussäestys; } \\
\text { yrt. '1965') } \\
0\end{array}$ & \begin{tabular}{l} 
säestys kuten \\
Ai :ssä $\ldots \ldots$ \\
\hdashline$\ldots$
\end{tabular} & $\begin{array}{l}\text { säestys kutẹn } \\
\text { Ai :ssä. . . . }\end{array}$ & $\begin{array}{l}\text { söestys kuten } \\
\text { Ai :ssä. . . }\end{array}$ & söestys kuten: & 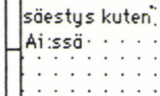 \\
\hline
\end{tabular}

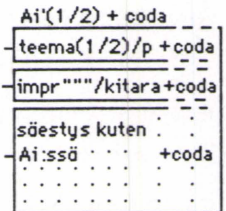

(kesto 6'00)

Kaavio 1 havainnollistaa L'Impossible-versioiden eroja kokonaismuodon, soitinnuksen ja improvisaatio-osuuksien suhteen.

Yksi laatikko vastaa pituudeltaan 9:āā $8 \times 1 / 4-$ nuotin pituista jaksoa (yht. 72 'iskua'). Kehystāmāttömāt jaksot ovat luonteeltaan solistia tukevia. Sāestys ('komppi') on kauttaaltaan tārkeā - siis kehystetty. Improvisaatioiden yksityiskohtia ei ole tarkemmin eritelty, mutta yleisenā periaatteena nāyttāā olevan, ettā perākkāiset improvisaatioosuudet (esim. impr - impr - impr . - ...) muuttuyat sāyelkudokseltaan kerta kerralta 'tiheāmmiksi". (Tarkempi selvitys tekstissā.) 
saatio-"kaavoista", ei ole kovinkaan olennaista, sillä jyrkkää eroa näiden kaavatyyppien välille ei koskaan voidakaan tehdä. Petersonin L'Impossiblen erottaa pelkkien sävelmä-"kaavojen" pohjalta syntyneistä improvisaatioista se, että "kaavaan" sisältyy paitsi tietty "sävelmä" säveltasoineen, myös tietty rytmi, säestys, säerakenne, karakteeri jne. Kaaviossa 1 A:lla symbolisoitu piano-osuuden sävelkudos on molemmissa versioissa täysin samanlainen - aina tempoa myöten; vain minimaaliset erot koristekuvioissa ja aksentuoinnissa erottavat versiot toisistaan. Myöhemmässä versiossa piano-osuus ei tosin esiinny kertaakaan sinällään ilman rytmisektion säestystä, kuten ensimmäisen version alussa.

L'Impossible-"kaavaan" kuuluu ilmeisesti myös basson osuus. Improvisointipohjaisessa välijaksossa (KAAVIO 1: BI->BI") ensimmäisen version (1965) basso-osuus poikkeaa pääjakson (jakso A -> A") "kaavasta"; myöhemmässä versiossa (1983) basso noudattaa alusta loppuun alkuperäistä "kaavaa" - tietyin improvisatorisin muunnoksin tietenkin. Näillä perusteilla voidaan esittää kaksi vaihtoehtoa: 1) Petersonin teos-"kaava" L'Impossible on 1965-version jakson A" mukainen tai 2) varsinainen "kaava" on 1965-version jakso A, mutta ensimmäisen version basistin bassoimpro-

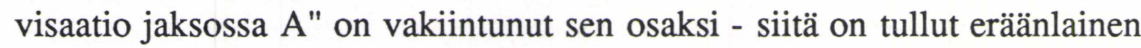
mallitulkinta, jonka arvovalta koko "kaavan" kannalta on lähes yhtä suuri kuin Petersonin piano-osuuden, siis itse "kaavan". Mikä Petersonin varsinainen teos-"kaava" sitten onkin, siihen kuuluu vaatimus ensin ensisijaisesti tulkita, sitten improvisoida ja jälleen lopuksi tulkita. Näin selittyvät yllä analysoitujen versioiden erot ja yhtäläisyydet.

Berendt on kuvannut vakiintuneiden mallitulkintojen muodostumista jazz-kulttuurissa yleisesti seuraavasti (1976: 127-128):

The habits of jazz ensure that the most important jazz themes repeatedly become the foundations for the improvisations of jazz musicians. They are played day after day and night after night in hundreds of clubs and concert halls. After 100 or 200 choruses [improvisoitu muunnos], a musician may arrive at certain phrases which then will crop up more and more frequently in his playing of the tune. After a while something like a "standandard chorus" on the respective theme will have developed. Many choruses have become so famous that the listener would be disappointed if the musician who made them up suddenly were to play something different.

Normaalitapauksessa vakiintuneet mallitulkinnat ovat siis henkilökohtaisia - eivät yleispäteviä, sillä improvisointitapa on osa improvisoijan persoonallisuutta. Berendtin mukaan tällaiset mallitulkinnat ovat jäljittelemättömiä: niitä ei voida erottaa luojistaan esim. nuotintamalla ja antamalla jonkun toisen esittää ne. Jos näin tapahtuu, ne menettävät karakteerinsa, "and no- 
thing remains but the naked formula of notes". Petersonin L'Impossiblen basso-osuus (A) näyttää sen sijaan olevan yleispätevä (ensimmäisen version basisti oli Ray Brown, jälkimmäisen N. H. Örsted-Pedersen), mistä voitaisiin päätellä sen kuuluvan itse asiassa varsinaiseen teos-"kaavaan". Sen sijaan improvisatoristen välijaksojen yhtäläisyydet (joitain samantapaisia soittokuvioita) eivät kuulu teos-"kaavaan" L'Impossible vaan Petersonin improvisointityyliä kaiken kaikkiaan luonnehtiviin ja jossain määrin kaikelle piano-jazzille ominaisiin "yleisiin kaavoihin". Molemmat versiot noudattavat myös saman tapaista $\mathrm{ABA}$ "-muotokaavaa, jota ei sitäkään voida pitää nimenomaan L'Impossible -"kaavan" karakteristisena ominaisuutena vaan perinteiseen jazz-improvisaatioon kuuluvana "yleisenä kaavana". Sitä noudattavat myös Petersonin Lefcon ja Wellsin "sävelmän" You Look Good To Me pohjalta tekemät improvisaatiot vuosilta 1964 (Verve 8100471) ja 1981 (Pablo D2308231). Nämä kaksi mainitun "sävelmän" mukaan nimettyä improvisaatioversiota eroavat jyrkästi toisistaan ennen kaikkea "sävelmän" erilaisen rytmisen käsittelyn vuoksi: ensimmäinen versio on hitaan kehtolaulun kaltainen ja tasaisessa rytmissä, toinen puolestaan nopea ja "pisteellisessä" rytmissä. "Sävelmä", johon molemmat versiot pohjautuvat, on tulkittu autenttisesti ainoastaan harmoniankulun päälinjojen ja melodisten säveltasojen suhteen. Itse karakteerit ovat rytmisen hahmon vuoksi täysin erilaiset.

L'Impossiblesta ja You look Good To Me -improvisaatioista poikkeava suhde "kaavoihin" on Petersonin Blues Etudessä vuodelta 1973 (Pablo 2310701) - joka muuten identtisestä nimestään huolimatta on erilainen kuin Blues Etude vuodelta 1966 (Mercury 6641577). "Etydi 1973" on sikäli täysin "vapaa improvisaatio", että sen perustana ei ole mitään selvästi erottuvaa sävelmä-"kaavaa"; improvisaatiota ohjailevat "yleiset nopean bluesin kaavat". Toisaalta Peterson käyttää joitain traditionaalisen pianoetydikirjallisuuden alkeellisimpia sävelkulkuja, eräänlaisia sormiharjoituskuvioita, joita voidaan pitää yleisinä virtuoosisen musiikin "kaavoina". Ylimalkaan tälle improvisaatiolle on leimallista perpetuum mobile -tunnelma ja Petersoninkin taiturilliseen tyyliin nähden poikkeuksellinen artistisuus, joka paikotellen tuntuu täysin itsetarkoitukselliselta. Itsetarkoituksellinen artistisuus ja nopea blues, siinä Blues Etuden (1973) "kaavan" karakteristisimmat piirteet.

\section{Joitain yleistyksiä}

Keskustelu sävellyksen ja tulkinnan osuudesta jazz-musiikissa luo aasinsillan (?!) länsimaiseen taidemusiikikin. Ennen yksityiskohtaisesti nuotinne- 
tun ja suunnitellun teos-"kaavan" vakiintumista ainoaksi vaihtoehdoksi 1800-luvulla, monet arvostetut säveltaiteilijat korostivat ilmaisukarakteerin säilymisen ja voimistumisen tärkeyttä esityksessä: improvisoiden tulkitsevan esittäjän tuli aina noudattaa "kaavan" affektisisältöä. Saman kaltaisia ajatuksia ovat esittäneet myös eräät jazz-muusikot, kuten esimerkiksi Ornette Coleman, joka on korostanut sävelmä-"kaavan" merkitystä kokonaisuuden kannalta: "sävelmän" peruskarakteerin tulee kuulua improvisaation jokaisessa soitetussa sävelessä (ks. Berendt 1976: 110-111). Mielenkiintoista kyllä, Coleman on korostanut olevansa "ensi sijassa säveltäjä, ei solisti tai yhtyeen johtaja" (ks. Harri Uusitorppa, Helsingin Sanomat, 3.10.1987, s.35). Tämä selittää sen, että hän korostaa ennalta laaditun suunnitelman - sävelmä-"kaavan" - merkitystä jazz-improvisaatiossa, mikä ei ainakaan jazz-kulttuurissa ole itsestäänselvyys - siitä kertovat jo yllä mainitut Petersonin improvisaatio-versiot sävelmästä You Look Good To $M e$ : saman sävelmä-"kaavan" pohjalta kaksi täysin erisävyistä improvisaatioversiota. Colemanin vaatimukseen sisältyy ajatus sävelmästä "kaavana", jossa kiteytyy tietty ekspressiivis-konstruktiivinen merkityssisältö. Myös sävelmä-"kaava" on sen mukaan tulkittava niin autenttisesti kuin mahdollista. Tätä taustaa vasten näyttäisi olevan mahdollista jakaa jazz-kulttuurikin tulkinta- ja improvisaatiopainotteiseen haaraan. Edellisen piirissä musiikillista toimintaa hallitsee pyrkimys paljastaa, tulkita "kaavan" merkityssisältö - jälkimmäisen piirissä ennalta laadittu "kaava" on malli jollekin sävelkudoksen aspektille ja ohjailee sen kautta automaattisesti improvisaatiota ilman, että esittäjä erityisesti pyrkisi sitä tulkitsemaan.

\section{Lähteet}

Adorno, Th. W.

1975 Einleitung in die Musiksoziologie. Zwölf theoretische Vorlesungen. Frankfurt am Main: Suhrkamp Taschenbuch Verlag.

Berendt, Joachim

1976 The Jazz Book. Frogmore, St Albans, Herts: Paladin.

Busoni, Ferruccio

1956 Wesen und Einheit der Musik. Berlin: Max Hesse.

Dahlhaus, Carl

1980 Die Musik des 19. Jahrhunderts. - Neues Handbuch der Musikwissenschaft 6 Hrsg. C. Dahlhaus. Wiesbaden:Athenaion.

Dauer, Alfons Michael

1985 "Tradition afrikanischer Blasorchester und Entstehung des Jazz (Texteil)". - 
Beiträge zur Jazzforschung 7. Graz: Akademische Druck- und Verlaganstalt. Gridley, Mark C.

1978 Jazz Styles. Englewood Cliffs, New Jersey: Prentice-Hall.

Griffiths, Paul

1981 Modern Music. The Avant Garde since 1945. London: Deut. Hegel, G. W.

1970 Vorlesungen über Ästhetik. Frankfurt am Main: Surkamp.

Ingarden, Roman

1962 Untersuchungen zur Ontologie der Kunst. Tübingen: Max Niemeyer.

Lück, Rudolf

1971 Werkstattgespräche mit Interpreten neuer Musik. Köln: Hans Gerig.

Mark, Thomas C.

1981 "Philosophy of piano playing: reflections on the concept of performance". -

Philosophy and phenomenological research xli. Mar 1981: 299-324.

Mauerhofer, Alois

1979 "Instrumentaler Flamenco als klingender Ausdruck einer spezifischen Gitarretechnik". -Studia instrumentorum musicae popularis VI: 103-110. toim. Erich Stockmann. Stockholm: Musikhistoriska museet.

Mäkelä, Tomi

1986a "Soittimellisuuden ongelmasta ja analysoinnista musiikissa". Musiikki 1/1986: 5 2-67.

1986b "Uutta ensi käden tietoa Händelin esityskäytännöstä?" - Musiikki 2/1986: 149158.

1987 "Soitinmusiikin soittimellisuudesta tyylianalyyttisena parametrina". Lisensiaatintyö. Helsingin yliopisto.

1987a "Soittimellisuus musiikin lähtökohtana? Näkökulma Th. W. -Adornon myöhäisromanttiseen soittimellisuuskritiikkiin". - Synkooppi 2/1987: 6-13.

1987b "Taktiilinen sävel ja notaatiot. Näkökulma soittimellisuuden tutkimukseen". Synteesi 3/1987: 56 -66.

1987c "Instrumental Figures as Iconic Signs". - The Semiotic Web "86. An International Yearbook. s. 571-575. toim. Thomas A. Seboek and Jean UmikerSebeok. Berlin: Mouton de Gruyter.

1987d "Essai sur l'instrumentivité: les notations musicales comme signes iconiques. Degrés. 53. 1988, printemps. s. g-g25.

1987 e "Musica naturalis et artificialis - vokaali ja instrumentaalimusiikin tyylidikotomian perusteista länsimaisessa taidemusiikissa". - Musiikki 2/1987. (toimituksessa)

1988 "Improvisaatio, tulkinta ja virtuoosisuus: alustavia havaintoja musiikillisen luovan toiminnan muodoista ja manifestaatioista esittävässä säveltaiteessa". Synteesi 1-2 ja 4/87. 
Nettl, Bruno

1974 "Thoughts on Improvisation: A Comparative Approach". - The Musical

Quarterly ix/1: 1-19

Neumann, Fredrick

1982 Essays in performance practice. Ann Arbor, Michigan: UMI ResearchPress.

Nowacki, Rafal

1982 "On the Interpretation of Music". -Polish Art Studies 3: 103-112.

Ratner, Leonard G.

1980 Classic Music. New York/London: Schirmer/Collier Macmillan.

Stravinsky, Igor

1957 Igor Strawinsky. Leben und Werk - von ihm selbst. Mainz: B. Schott's Söhne.

Wieck, Friedrich

1853 Clavier und Gesang. Didaktisches und Polemisches. Leipzig: Whistling.

\section{Summary}

On the performing and composing activity in music - especially in jazz

The analysis of music as a performing art is only possible if the dialectical character of the relation between performing and composing activities in music can be operationalized. The activity of a composer manifests itself in plans which can also be called models - a concept often used to describe forms like the Arabian maqam or the Indian raga. All kinds of sets of rules dictating the nature and details of a performance can be called models. The notation - often thought to be one of the necessary characteristics of a composition - is of course not at all essential to a model. Notation is, as Busoni put it, only one transcription of the original idea of the composer; another transcription is, according to Busoni again, the performance. The performer of a given model thus takes the notation (if existing) as one object, but by no means the only one, of his interpretation. His aim is to understand the model itself. In preindustrialized, more intimate musical cultures the model was often orally transmitted, and not at all so detailed as in late 19th century music as far as the individual tones are concerned.

A model can be either general or specific - that is, either common to a certain musical culture as a whole or only specific to a particular, individual manifestation of musical activity. The general models define the so-called styles of music as well as characteristic forms. Compositional technics like the topics of the 18th century or serialism are also general 
models, as well as the so-called performance practices and other "schools". The most common European kind of specific model is the composition or piece of music; in India it is the raga and in traditional jazz the arrangement. According to Berendt (1976), "the arrangement in jazz begins at the moment something is agreed upon in advance". Arrangement is thus a model, mostly based on another model called tune.

In general, a model is anything that gives a musical activity its form of manifestation. The activity called composing aims at preparing new models for performances. The pure performer does not have this aim; he is making music based on a variety of models. The manifestation is the result of the activity: the manifestations of the composing activity are models, whereas the manifestations of performing activity are performances based on models. The composition-models in western art music have not always been as detailed as they have been from the late 19th century on. Many kinds of compositions have been developed from rather detailed improvisation-models like variation, the ostinato-forms and toccatas, which were called compositions as soon as the plan was made before the performance and it was mostly notated; the difference between a composition and an improvisation of the performer was anything but clear. An essential aspect of a piece of music was not its tones and notes as such but its character and affect - which were communicated by the specific models most closely related to the general models.

The manifestations of musical activity can be either primarily compositional or performing. The purest forms of manifestations are the composition model of German romanticism in the late 19th century, and a totally spontaneous improvisation based only on general models in a given musical culture. A special case is the collective folk tunes, which may also act as models but which are a property of a collectivity, not of an individual composer. They are often formed by a number of people of different generations. They reflect the general models of a culture more directly than other kinds of manifestations. The general models are also mostly collectively prepared - though not necessarily, since the compositional schools with their characteristic manners are often based on innovations by a given individual composer.

It may be necessary to underline that composing does not mean here the production of new musical structures in general, but planning a set of rules for the performance. The performer often produces new musical structures either by improvising some details or just by interpreting innovatively - but he is not composing. Improvising is composing only if the aim of the activity is planning new models. If the performer plans either his interpretation or his improvisation before the performance - 
which is often the case - he is preparing detailed models for his performance and thus acting as a composer. Here we can see the complex dialectics of musical activities.

The so-called interpretation of a model is actually always a composing activity, since only a detailed preparatory planning of a performance based on a given model is a true interpretation of it. When Leopold Mozart, on the other hand, demands that a performer should take a look at the piece in order to get an idea of its character before starting to perform it, he takes for granted that the piece of music can be performed without its detailed interpretation on the basis of the general model - Rattner would say: the given topic. The performer should realize the general model of the piece and after that perform the detailed model (that is, the piece) in the closest relation to the given general model he is already familiar with. The composer relies here on models common to himself and the performer.

In this paper the concept of a model is discussed with recent ideas on the concepts of musical work, composing, arrangement, improvisation, interpretation and performance in general. A special emphasis is given to topics in jazz music. A broader discussion of these questions may be found in our paper Improvisaatio, virtuoosisuus ja tulkinta (1988). 